\title{
Unit Commitment Pada Sistem Pembangkitan Tenaga Angin Untuk Mengurangi Emisi Dengan Menggunakan Particle Swarm Optimization
}

\author{
Muhammad Arindra, Rony Seto Wibowo, dan Dedet Candra Riawan \\ Jurusan Teknik Elektro, Fakultas Teknologi Industri, Institut Teknologi Sepuluh Nopember (ITS) \\ Jl. Arief Rahman Hakim, Surabaya 60111 \\ e-mail: ronvseto@ee.its.ac.id.dedet.riawan@ee.its.ac.id.arindra.muhammad@gmail.com.
}

\begin{abstract}
Abstrak - Permintaan daya listrik yang terus bertambah menyebabkan daya listrik yang disuplai oleh pembangkit menjadi lebih besar. Kondisi beban yang harus disuplai pembangkit selalu berubah-ubah tiap waktunya, maka penyaluran energi listrik haruslah sesuai antara energi yang terbangkitkan oleh pembangkit dengan jumlah beban yang harus disuplai untuk memperoleh biaya pembangkitan yang paling ekonomis. Pada Tugas Akhir ini untuk mendapatkan biaya yang ekonomis akan dilakukan penjadwalan pembangkit yang optimal. Penjadwalan pembangkitan bertujuan untuk mendapatkan biaya operasional yang minimum tetapi tetap dapat memenuhi permintaan beban yang ada.

Penggunaan generator dengan bahan bakar fosil dapat memberikan efek pencemaran lingkungan akibat emisi sisa dari pembakaran. Melihat permasalahan yang ada, penggunaan turbin angin, merupakan solusi yang tepat. Penggunaan turbin angin amat bermanfaat untuk mengurangi emisi yang dihasilkan oleh generator konvensional. Selain dapat mengurangi emisi yang dihasilkan, penggunaan turbin angin dapat mengurangi biaya operasional, karena penggunaan turbin angin tidak memerlukan energi fosil sebagai bahan bakar.
\end{abstract}

Kata Kunci - Unit Commitment, Particle Swarm, Optimization, Optimal Power Flow, Turbin Angin, Emisi.

\section{Pendahuluan}

$\mathrm{U}$ NTUK memenuhi kebutuhan energi manusia dibutuhkan kapasitas pembangkit yang terus meningkat sehingga mengharus menggunakan pembangkit lebih dari satu unit pembangkit yang beroperasi [1]. Jumlah beban yang harus disuplai pembangkit selalu berubah-ubah tiap waktu nya. Oleh karena itu, penyaluran energi listrik haruslah sesuai antara energi yang terbangkitkan oleh pembangkit dengan jumlah beban yang harus disuplai untuk memperoleh biaya pembangkitan yang paling ekonomis. Untuk mendapatkan biaya pembangkitan yang ekonomis, diperlukan suatu mekanisme pembagian pembebanan pada pembangkitan yang biasa disebut dengan Optimal Power Flow. Optimal Power Flow merupakan perhitungan pembagian pembebanan pembangkit dengan mempertimbangkan aliran daya. Selain diperlukannya mekanisme pembagian pembebanan, diperlukan juga suatu mekanisme penjadwalan penyambungan dan pelepasan unit pembangkit yang disebut Unit Commitment (UC). Unit Commitment merupakan penjadwalan waktu penyalaan unit pembangkit pada system tenaga listrik yang direncanakan dalam waktu yang berbeda-beda. Dalam penjadwalannya UC juga mempertimbangkan kondisi optimal ekonomi, dan batasan-batasan teknis pengoperasian pembangkitan.

Penggunaan sumber energi listrik yang dapat diperbarui merupakan salah satu cara untuk mendapatkan biaya pembangkitan yang ekonomis, karena tidak memerlukan bahan bakar fosil sebagai bahan bakarnya. Salah satu sumber energi listrik yang menggunakan energi terbarukan adalah penggunaan turbin angin, dimana pada sistem pembangkitan menggunakan turbin angin hanya menggunakan bahan bakar sebagai sumber energi generator konvensional saja [2]. Dalam penggunaan turbin angin pada sistem pembangkitan energi listrik dapat dihasilkan secara langsung, sehingga dapat membantu memenuhi permintaan beban.

Selain mendapatkan biaya pembangkitan yang ekonomis, faktor yang penting diperhitungkan adalah kadar emisi yang dihasilkan oleh sistem pembangkitan. Atas pertimbangan kondisi bumi yang semakin memburuk, dampak dari emisi akan sangat berpengaruh terhadap kondisi bumi khusus nya lapisan atmofser. Pada sistem pembangkitan menggunakan turbin angin yang diintegrasikan dengan generator konvensional akan tetap menggunakan bahan bakar fosil dan menghasilkan emisi sisa pembakaran. Sulphur Oxide (SO2), Carbon Oxide (CO2), dan Nitrogen Oxide (NOx) merupakan emisi berbahaya yang dihasilkan dari sisa pembakaran, yang dapat menyebabkan pencermaran lingkungan, maka dari itu kadar emisi tersebut harus segera dikurangi karena dampak yang dihasilkan berbahaya.

Pada penelitian ini akan dilakukan penjadwalan terhadap unit pembangkitan agar di dapatkan biaya operasional yang ekonomis. Pada sistem pembangaktian akan digunakan turbin angin yang terhubung dengan generator konvensional. Dimana pada penelitian ini akan dianalisa juga efek dari penggunaan turbin angin pada sistem pembangkitan yang dimana akan berpengaruh terhadap kinerja generator konvensional dan emisi yang dihasilkan.

\section{TINJAUAN PUSTAKA}

\section{A. Unit Commitment}

Unit commitment merupakan penjadwalan hubung-lepas pembangkitan unit pembangkit pada sistem tenaga listrik dalam kurun waktu tertentu, dengan tujuan untuk memenuhi permintaan beban. Penjadwalan ini biasanya ditentukan berdasarkan permintaan beban manusia yang selalu berubah-ubah tiap waktunya. Tujuan utama dari penjadwalan ini adalah untuk mendapatkan biaya pembangkitan yang ekonomis dalam periode waktu tertentu, namun tetap mempertimbangkan batasan-batasan operasi yang ada. Setip unit pembangkit memiliki berbagai batasan operasi seperti spinning reserve, minimum up-down time, pembangkitan daya maksimum dan minumin, dan biaya penyalaan unit pembangkitan. Dibeberapa kasus konfigurasi jaringan transmisi juga dipertimbangkan, hal ini karena jaringan transmisi akan mengatur aliran daya maksimum yang dapat mengalir pada suatu saluran. 
Permasalahan Unit Commitment merupakan kombinasi dari dua sub-masalah. Pertama adalah menentukan unit pembangkit yang akan dinyalakan. Kedua adalah menentukan jumlah biaya generasi dari masing-masing unit yang berkomitmen. Unit pembangkit memiliki perbedaan efisiensi operasi dan karakteristik kinerja yang merefleksikan inputan yang dibutuhkan. Dengan demikian, operasi UC diselesaikan dalam dua tahap. Kombinasi unit pembangkit yang menghasilkan biaya produksi paling ekonomis akan dipilih sebagai jadwal UC untuk setiap jam [3].

Dalam penjadwal pembangkitan, akan dicari kombinasi yang optimum untuk mendapat biaya pembangkitan yang murah. Kombinasi yang digunakan merupakan kombinasi dari unit yang beroperasi dan unit tidak beroperasi, yang nanti akan digunakan unutk melakukan perhitungan pembangkitan. Dalam menentukan kombinasi yang digunakan ada bebrapa metode yang dapat digunakan yaitu,

1. Priority list atau urutan prioritas

Priority list merupakan kombinasi dalam penjadwalan pembangkit dengan mempertimbangkan biaya pembangkitan yang paling murah.

2. Complete Enumeration

Complete enumeration merupakan kombinasi dalam perhitungan penjadwalan pembangkit dengan memperhitungkan seluruh kombinasi yang mungkin terjadi.

Pada permasalahan yang ada unit commitment digunakan unutk mendapatkan biaya operasional yang optimal dan menjaga lifetime dari setiap unit pembangkit. Unutk mendapatkan dua hal tersebut ada beberapa batasan yang digunkan pada unit commitment yaitu sebagai berikut:

1. Spinning Reserve (Cadangan Berputar)

Spinning reserve adalah jumlah total energi yang tersedia, dari hasil pembangkitan semua unit pembangkit, dikurangi dengan beban dan kerugian yang ada pada sistem tenaga listrik. Cadangan yang dimiliki setiap unit pembangkit yang beroperasi harus dapat manggulangi daya yang berkurang pada sistem, akibat adanya unit pembangkit yang mengalami kegagalan operasi sehingga penurunan dari frekuensi sistem masih berada pada kondisi aman.

2. Thermal Unit Contrains

Thrmal unit dapat hanya dapat beroperasi jika terjadi perubahan temperature, perubahan temperature akan mempengaruhi pada batasan waktu menyalakan dan memadamkan unit, oleh karena itu terdapat berbagai kondisi operasi thermal unit seperti,

- Minimum up time

- Minimum donw time

3. Star Up Cost

Star up cost merupakan biaya yang dibutuhkan oleh unit pembangkit untuk start dari kondisi tidak beroperasi samapai unit pembangkit beroperasi. Ada beberapa jenis kondisi penyalaan unit pembangkit yaitu,

- Cold temperature starting

- Working temperature starting

\section{B. Fungsi Objektif unit commitment}

Secara teoritis fungsi objektif unutk penjadwalan unit commitment adalah jumlah seluruh biaya operasi di jumlahkan dengan biaya penyalaan dan pemadaman tiap unit pembangkit yang menyuplai daya di setiap jam nya.

$$
F_{H}=\sum_{h=1}^{H} \sum_{n=1}^{N}\left[\begin{array}{c}
{\left[F_{n h}\left(p_{n h}\right)+C S C_{n h}\left(1-u_{n(h-1)}\right)\right] u_{n h}} \\
+D C_{n h}\left(u_{n(h-1)}-0\right)
\end{array}\right.
$$

Biaya bahan bakar unit pembangkit,

$$
F_{n h}\left(p_{n h}\right)=a_{n}\left(p_{n h}\right)^{2}+b_{n}\left(p_{n h}\right)+c_{n}
$$

Waktu nyala minimum,

$$
T_{n}^{o n} \geq M U T_{n}
$$

Waktu padam minimum,

$$
T_{n}^{o n} \geq \mathrm{MUT}_{n}+\mathrm{CSH}_{n}
$$

Kesetimbangan daya

$$
\sum_{n=1}^{N} p_{n h}=D_{h}
$$

Rentang daya pembangkitan

$$
U_{n h} p_{n(\max )} \geq p_{n h} \geq U_{n h} p_{n(\min )}
$$

\section{Keterangan}

$\mathrm{N} \quad$ = Jumlah unit pembangkit yang digunakan

$\mathrm{H} \quad$ = Jumlah periode jam penjadwalan

$\mathrm{n}, \mathrm{h} \quad \quad=$ Indeks unit $(1,2,3, \ldots)$

$p_{n h} \quad=$ Variable control untuk pembangkit $\mathrm{n}$ pada jam h

$U_{n h} \quad=$ Variabel control status nyala/mati unit

pembangkit $n$ pada jam $\mathrm{h}$

$F_{h} \quad=$ Biaya total pembangkitan pada jam $\mathrm{h}$

$F_{n h}\left(p_{n h}\right) \quad=$ biaya operasi unit $\mathrm{n}$ pada jam $\mathrm{h}$

$a_{n}, b_{n}, c_{n} \quad=$ Koefisien fungsi biaya unit $\mathrm{n}$

$C_{n h} \quad=$ Biaya penyalaan saat kondisi dingin unit $\mathrm{n}$

$\mathrm{CSH}_{n} \quad$ = Waktu penyalaan saat kondisi dingin unit $\mathrm{n}$

$M_{n} \quad$ = Waktu nyala minimum unit $\mathrm{n}$

$M D T_{n} \quad$ = Waktu padam minimum unit $\mathrm{n}$

$D C_{n h} \quad=$ Biaya pemadaman uni $\mathrm{n}$ pada jam $\mathrm{h}$

$T_{n}^{\text {on }} / T_{n}^{\text {off }} \quad=$ Rentang waktu selama unit $\mathrm{n}$ menyala atau

$D_{h} \quad$ = Permintaan beban puncak pada jam $\mathrm{h}$

$p_{n(\max )} / p_{n(\min )}=$ Daya output maksimal $/$ miimal unit $\mathrm{n}$

\section{Optimal Power Flow}

Optimal power flow merupakan pengembangan dari economic dispatch yang memperhitungkan aliran daya. OPF berfungsi melakukan pembagian pembangkitan pada tiap unit pembangkitan dengan memperhitungkan aliran daya pada saluran dengan total biaya yang minimal.

Fungsi objektif dari OPF adalah menentukan total biaya yang optimal pada sistem. Untuk mendapatkan total biaya yang optimal dapat meminimalkan biaya bahan bakar, yang berkaitan dengan besarnya pembangkitan pada masing masing unit pembangkit. Meminimalkan biaya kerugian pada pelepasan beban juga dapat berpengarug pada biaya produksi. Proses pelepasan beban biasa nya digunakan untuk mendapatkan sistem yang diinginkan. Dampak dari pelepasan beban akan dapat merugikan konsumen.

Perhitungan optimasi pada $O P F$ mencakup:

a) Fungsi objektif:

Fungsi objektif berupa total biaya pembangkitan (satuan mata uang/jam) 


$$
\min \sum_{i=1}^{N_{\text {bus }}} F_{i}\left(P_{i}\right)
$$

Indeks nomor bus ditunjukkan oleh $i$, dan $F_{i}\left(P_{i}\right)$ merupakan fungsi biaya generator.

b) Inequality constraint generator:

Untuk $i$ dari 1 hingga sejumlah $n$ bus

$$
\begin{aligned}
& P_{\text {gen }_{i}}^{\min } \leq P_{\text {gen }_{i}} \leq P_{\text {gen }_{i}}^{\max } \\
& Q_{\text {gen }_{i}}^{\min } \leq Q_{\text {gen }_{i}} \leq Q_{\text {gen }_{i}}^{\max }
\end{aligned}
$$

Untuk perhitungan yang lebih mendekati keadaan real sistem, persamaan OPF dapat ditambahkan dengan batasan batasan lain, misalnya inequality constraint kapasitas saluran, inequality constraint tegangan pada bus, dan sebagainya.

Dynamic optimal power flow merupakan pengembangan dari OPF yang menggunakan beban yang dinamis. Beban yang berubah ubah ini akan digunakan sebagai parameter untuk penjadwalan pembangkitan. Pada tugas akhir ini di asumsikan beban akan berubah tiap rentang selama satu jam.

\section{Emisi}

Dalam setiap operasi system tenaga listrik ada dua hal yang perlu diperhatikan yaitu, biaya pembangkitan dan emisi gas buang dari masing masing unit pembangkit. Bebrapa pembangkit listrik yang menggunakan bahan bakar fosil akan menghasilkan emisi dari sisa pembakaran. Emisi tersebut dapat berupa Sulfur Dioksida (SO2), Karbon Dioksida (CO2), dan Nitrogen Oksida (NOx). Untuk perhitungan emisi dapat digunakan persamaan berikut:

$$
E(P)=\sum_{i=1}^{N} 10^{-2}\left(\alpha_{i}+\beta_{i} P_{i}+\gamma_{i} P_{i}^{2}\right)+\zeta_{i} \exp \left(\lambda_{i} P_{i}\right)
$$

dimana $\alpha_{i}, \beta_{i}, \gamma_{i}, \zeta_{i}$, dan $\lambda_{i}$ adalah koefisien non-negatif dari karakteristik emisi generator unit- $i$.

Keterangan,

$E(P)=$ total emisi generator dalam $\mathrm{g}$

$\alpha_{i}=$ koefisien non-negatif SO2

$\beta_{i}=$ koefisien non-negatif $\mathrm{CO} 2$

$\gamma_{i}=$ koefisien non-negatif $\mathrm{NOx}$

\section{PENERAPAN PSO PADA PENJADWALAN SISTEM PEMBANGKITAN}

\section{A. Particel Swarm Optimization}

Particle Swarm Optimization (PSO) adalah metode optimasi yang berbasis berdasarkan populasi burung yang di kembangkan pada tahun 1995, dimana pada metode ini tiap individu diumpamakan sebagai partikel. Partikel ini berfungsi sebagai calon pemberi solusi dari permasalhan yang akan di optimasikan, dimana dalam mencari solusi tiap partikel ini akan mengganti posisi dan kecepatan nya tiap waktu. Dalam proses mencari nilai yang optimum, setiap partikel akan menentukan posisi terbaiknya sendiri berdasarkan posisi nya sendiri (local best) dan posisi partikel lain nya(global best). Proses pencarian Pbest dan Gbest dapat diilustrasikan pada gambar berikut

Pencarian solusi dilakukan oleh banyak partikel dalam suatu populasi tertentu. Setiap partikel akan mempresentasikan solusi dari permasalahan berdasarkan posisi yang dimiliki. Dalam menentukan posisi tiap partikel akan menyesuaikan dengan posisi terbaik partikel dan posisi terbaik populasi pada waktu yang sama. Jadi penyebaran pengalaman terjadi pada partikel itu sendiri dan antara partikel itu sendiri dengan partikel terbaik pada populasi tersebut. Setelah proses ini dilanjutkan dengan mencari posisi terbaik partikel dengan melakukan iterasi. Iterasi dilakukan unutk mendapatkan mendapatkan posisi yang relatif stabil dalam batas iterasi yang ditetapkan.

Setiap partikel diperlakukan seperti sebuah titik pada suatu dimensi ruang tertentu. Kemudian terdapat dua faktor yang memberikan karakter terhadap status partikel pada ruang pencarian yaitu posisi partikel dan kecepatan partikel [4].

Faktor lain yang dibutuhkan tiap partikel untuk menentukan solusi adalah kecepatan. Kecepatan ini berguna untuk mentukan seberapa cepat sebuah partikel menemukan posisi yang optimal. Tiap iterasi kecepatan akan terus berubah se iring dengan posisi partikel yang terus di evaluasi. Perubahan posisi dan kecepatan partikel dapat di tentukan dengan persamaan berikut:

$\begin{aligned} V_{j(i)}= & V_{j(i-1)}+c_{1} r_{1}\left[P_{b e s t, j}-x_{j}(i-1)\right] \\ & +c_{2} r_{2}\left[G_{b e s t, j}-x_{j}(i-1)\right]\end{aligned}$

Dengan persamaan di atas kecepatan secara bertahap akan berubah semakin mendekati Pbest dan Gbest. Sedangkan update posisi dapat di tentukan dengan persamaan berikut:

$$
\begin{array}{ll}
x_{j(i)}=x_{j(i-1)+} V_{j(i)} \\
\text { Dimana, } \\
V \quad \text { : Kecepatan Partikel } \\
x \quad \text { : Posisi Partikel } \\
j & : \text { Indeks Partikel } \\
i & : \text { Iterasi ke-i } \\
c_{1}, c_{2} & : \text { Konstanta } \\
r, r_{2} & : \text { Bilangan Random } \\
\text { Pbest } & \text { : Posisi Terbaik Lokal } \\
\text { Gbest } & : \text { Posisi Terbaik Global }
\end{array}
$$

Pada awalnya fungsi PSO hanya mampu menyelesaikan permasalahan optimasi pada bilangan real, tetapi seiring berjalannya waktu fungsi PSO telah dikembangkan agar mampu menyelesaikan permasalahan optimasi pada bilangan biner, yang biasa disebut dengan Binary Particle Swarm Optimization (BPSO). Pada penggunaan BPSO ada disedikit perbedaan, terutama proses update posisi partikel tidak menggunakan persamaaan sebelum nya, melainkan menggunakan persamaan berikut :

$$
x_{j(i)}=\left\{\begin{array}{l}
1 \\
0
\end{array}\right.
$$

Berikut ini adalah langkah - langkah yang di lakukan pada PSO unutk mendapatkan nilai yang optimum

- Tentukan posisi awal dan kecepatan partikel secara acak.

- Evaluasi fitness dari setiap partikel berdasarkan posisinya.

- Tentukan partikel dengan fitness terbaik sebagai Gbest. Pada awal, Pbest akan sama dengan posisi awal

- Perbarui kecepatan partikel disetiap iterasi nya

- Dengan kecepatan yang baru dapat ditemukan posisi baru juga

Ulangi semua langkah sampai maksimal iterasi dipenuhi 


\section{SIMULASI DAN ANALISA}

\section{A. Hasil Simulasi}

Tabel 1 menunjukan penjadwalan pada kasus 1 yang merupakan merupakan penjadwal 6 pembangkit termal berbahan bakar. Tabel 2 menunjukan penjadwalan pada kasus 2 yang merupakan merupakan penjadwal 5 pembangkit termal berbahan bakar dan 1 pembangkit menggunakan turbin angin pada unit 6 , dimana kondisi awal semua pembangkit termal dalam keadaan mati dan turbin angin dalam keadaan menyala karena ketersedian angin yang mencukupi. Penjadwalan pembangkit dilakukan selama 24 jam dimana tiap jam memiliki kondisi beban yang berubah ubah

Tabel 1

Tabel penjadwalan pembangkit Kasus 1

\begin{tabular}{|c|c|c|c|c|c|c|}
\hline \multirow{2}{*}{ JAM } & \multicolumn{6}{|c|}{ "UNIT } \\
\hline & 1 & 2 & 3 & 4 & 5 & 6 \\
\hline 1 & 1 & 1 & 1 & 0 & 0 & 0 \\
\hline 2 & 1 & 1 & 1 & 0 & 0 & 0 \\
\hline 3 & 1 & 1 & 1 & 0 & 0 & 0 \\
\hline 4 & 1 & 1 & 1 & 0 & 0 & 0 \\
\hline 5 & 1 & 1 & 1 & 0 & 0 & 0 \\
\hline 6 & 1 & 1 & 1 & 0 & 0 & 0 \\
\hline 7 & 1 & 1 & 1 & 0 & 0 & 0 \\
\hline 8 & 1 & 1 & 1 & 0 & 0 & 0 \\
\hline 9 & 1 & 1 & 1 & 0 & 0 & 0 \\
\hline 10 & 1 & 1 & 1 & 0 & 0 & 0 \\
\hline 11 & 1 & 1 & 1 & 0 & 0 & 0 \\
\hline 12 & 1 & 1 & 1 & 0 & 0 & 0 \\
\hline 13 & 1 & 1 & 1 & 0 & 1 & 0 \\
\hline 14 & 1 & 1 & 1 & 0 & 1 & 0 \\
\hline 15 & 1 & 1 & 1 & 0 & 1 & 0 \\
\hline 16 & 1 & 1 & 1 & 0 & 0 & 0 \\
\hline 17 & 1 & 1 & 1 & 0 & 1 & 0 \\
\hline 18 & 1 & 1 & 1 & 0 & 0 & 1 \\
\hline 19 & 1 & 1 & 1 & 0 & 0 & 1 \\
\hline 20 & 1 & 1 & 1 & 0 & 1 & 0 \\
\hline 21 & 1 & 1 & 1 & 0 & 1 & 0 \\
\hline 22 & 1 & 1 & 1 & 0 & 0 & 0 \\
\hline 23 & 1 & 1 & 1 & 0 & 0 & 0 \\
\hline 24 & 1 & 1 & 1 & 0 & 0 & 0 \\
\hline
\end{tabular}

Tabel 2

Tabel penjadwalan pembangkit Kasus 2

\begin{tabular}{ccccccc}
\hline \hline \multirow{2}{*}{ JAM } & \multicolumn{7}{c}{ UNIT } \\
\cline { 2 - 7 } & 1 & 2 & 3 & 4 & 5 & 6 \\
\hline 1 & 0 & 1 & 1 & 0 & 0 & 1 \\
2 & 0 & 1 & 1 & 0 & 0 & 1 \\
3 & 0 & 1 & 1 & 0 & 0 & 1 \\
4 & 0 & 1 & 1 & 0 & 0 & 1 \\
5 & 0 & 1 & 1 & 0 & 0 & 1 \\
6 & 0 & 1 & 1 & 0 & 0 & 1 \\
7 & 1 & 1 & 1 & 0 & 0 & 1 \\
8 & 1 & 1 & 1 & 0 & 0 & 1 \\
9 & 1 & 1 & 1 & 0 & 0 & 1 \\
10 & 1 & 1 & 1 & 0 & 0 & 1 \\
11 & 1 & 1 & 1 & 0 & 0 & 1 \\
12 & 1 & 1 & 1 & 0 & 0 & 1 \\
13 & 1 & 1 & 1 & 0 & 0 & 1 \\
14 & 1 & 1 & 1 & 0 & 0 & 1 \\
15 & 1 & 1 & 1 & 0 & 0 & 1 \\
16 & 1 & 1 & 1 & 0 & 0 & 1 \\
17 & 1 & 1 & 1 & 0 & 0 & 1 \\
18 & 1 & 1 & 1 & 0 & 0 & 1 \\
19 & 1 & 1 & 1 & 0 & 0 & 1 \\
20 & 1 & 1 & 1 & 0 & 0 & 1 \\
21 & 1 & 1 & 1 & 0 & 0 & 1 \\
22 & 1 & 1 & 1 & 0 & 0 & 1 \\
23 & 1 & 1 & 1 & 0 & 0 & 1 \\
24 & 1 & 1 & 1 & 0 & 0 & 1 \\
\hline \hline
\end{tabular}

Tabel 3 dan Tabel 4 merupakan perhitungan dari biaya pembangkitan unit pembangkit pada kasus 1, dimana data yang diberikan merupakan data biaya yang diperlukan tiap jam nya dan total baiya pembangkitan selama 24 jam.

Perhitungan biaya dalam table tersebut merupakan perhitungan biaya dalam satuan mata uang dollar.

Tabel 3

Tabel biaya pembangkitan Kasus 1

\begin{tabular}{|c|c|c|c|c|}
\hline \multirow{2}{*}{ JAM } & \multicolumn{4}{|c|}{ Biaya $(\$)$} \\
\hline & Operasi & Penyalaan & Pemadaman & Pembangkitan \\
\hline 1 & 21.46 & 0.476 & 0 & 21.94 \\
\hline 2 & 20.1 & 0 & 0 & 20.1 \\
\hline 3 & 19.19 & 0 & 0 & 19.19 \\
\hline 4 & 20.77 & 0 & 0 & 20.77 \\
\hline 5 & 26.10 & 0 & 0 & 26.10 \\
\hline 6 & 22.51 & 0 & 0 & 22.51 \\
\hline 7 & 27.20 & 0 & 0 & 27.20 \\
\hline 8 & 29.82 & 0 & 0 & 29.81 \\
\hline 9 & 31.72 & 0 & 0 & 31.72 \\
\hline 10 & 30.95 & 0 & 0 & 30.95 \\
\hline 11 & 27.94 & 0 & 0 & 27.94 \\
\hline 12 & 28.69 & 0 & 0 & 28.69 \\
\hline 13 & 37.34 & 0.18 & 0 & 37.52 \\
\hline 14 & 36.56 & 0 & 0 & 36.56 \\
\hline 15 & 35.79 & 0 & 0 & 35.79 \\
\hline 16 & 32.49 & 0 & 0 & 32.49 \\
\hline 17 & 39.67 & 0.072 & 0 & 39.74 \\
\hline 18 & 41.42 & 0.113 & 0 & 41.54 \\
\hline 19 & 43.10 & 0 & 0 & 43.10 \\
\hline 20 & 40.44 & 0.18 & 0 & 40.62 \\
\hline 21 & 38.50 & 0 & 0 & 38.50 \\
\hline 22 & 33.65 & 0 & 0 & 33.65 \\
\hline 23 & 29.81 & 0 & 0 & 29.81 \\
\hline 24 & 27.94 & 0 & 0 & 27.94 \\
\hline \multicolumn{4}{|c|}{ Total Biaya Pembangkitan (\$) } & 744.30 \\
\hline
\end{tabular}

Tabel 4

Tabel biaya pembangkitan Kasus 2

\begin{tabular}{|c|c|c|c|c|}
\hline \multirow{2}{*}{ JAM } & \multicolumn{4}{|c|}{ Biaya (\$) } \\
\hline & Operasi & Penyalaan & Pemadaman & Pembangkitan \\
\hline 1 & 11.9819 & 0.413 & 0 & 12.3949 \\
\hline 2 & 10.8076 & 0 & 0 & 10.8076 \\
\hline 3 & 9.4642 & 0 & 0 & 9.4642 \\
\hline 4 & 11.2087 & 0 & 0 & 11.2087 \\
\hline 5 & 16.3988 & 0 & 0 & 16.3988 \\
\hline 6 & 12.741 & 0 & 0 & 12.741 \\
\hline 7 & 18.8956 & 0.176 & 0 & 19.0716 \\
\hline 8 & 20.8068 & 0 & 0 & 20.8068 \\
\hline 9 & 22.4429 & 0 & 0 & 22.4429 \\
\hline 10 & 22.4831 & 0 & 0 & 22.4831 \\
\hline 11 & 19.4794 & 0 & 0 & 19.4794 \\
\hline 12 & 19.6342 & 0 & 0 & 19.6342 \\
\hline 13 & 26.6445 & 0.18 & 0 & 26.6445 \\
\hline 14 & 25.7783 & 0 & 0 & 25.7783 \\
\hline 15 & 25.2441 & 0 & 0 & 25.2441 \\
\hline 16 & 23.15 & 0 & 0 & 23.15 \\
\hline 17 & 28.9281 & 0.072 & 0 & 28.9281 \\
\hline 18 & 30.3366 & 0.113 & 0 & 30.3366 \\
\hline 19 & 31.379 & 0 & 0 & 31.379 \\
\hline 20 & 29.5804 & 0.18 & 0 & 29.5804 \\
\hline 21 & 27.8098 & 0 & 0 & 27.8098 \\
\hline 22 & 24.2201 & 0 & 0 & 24.2201 \\
\hline 23 & 20.697 & 0 & 0 & 20.697 \\
\hline 24 & 19.1378 & 0 & 0 & 19.1378 \\
\hline \multicolumn{4}{|c|}{ Total Biaya Pembangkitan (\$) } & 509.84 \\
\hline
\end{tabular}


Tabel 5 dan Tabel 6 merupakan perhitungan emisi pada kasus 1. Pada table ini menunjukan emisi yang dihasilkan dari pembangkitan tiap generator. Pada generator unit 6 kasus 2 dimana menggunakan turbin angin tidak menghasilkan emisi karena menggunakan energy yang bersumber dari angin sebagai penggerak turbin. Dimana jenis emisi yang di hasilkan NOx, $\mathrm{SO}_{2}$, dan $\mathrm{CO}_{2}$. Jumlah emisi yang diberikan merupakan perhitungan jumlah emisi dalam 24 jam dalam satuan ton.

Tabel 5

Tabel emisi pembangkitan Kasus 1

\begin{tabular}{|c|c|c|c|c|c|c|c|}
\hline \multirow{2}{*}{$\begin{array}{l}\text { JENIS } \\
\text { EMISI }\end{array}$} & \multicolumn{6}{|c|}{ UNIT } & \multirow{2}{*}{$\begin{array}{c}\text { JUMLAH } \\
\text { (Ton) }\end{array}$} \\
\hline & 1 & 2 & 3 & 4 & 5 & 6 & \\
\hline Nox & 71.55 & 79.16 & 62.40 & 0 & 3.1 & 1.51 & 217.77 \\
\hline $\mathrm{SO} 2$ & 1.49 & 1.64 & 1.29 & 0 & 0.06 & 0.031 & 4.53 \\
\hline $\mathrm{CO} 2$ & 4.70 & 5.20 & 4.09 & 0 & 0.20 & 0.09 & 14.30 \\
\hline \multicolumn{7}{|c|}{ TOTAL } & TOTAL \\
\hline
\end{tabular}

Tabel 6

Tabel emisi pembangkitan Kasus 2

\begin{tabular}{|c|c|c|c|c|c|c|c|}
\hline \multirow{2}{*}{$\begin{array}{l}\text { JENIS } \\
\text { EMISI }\end{array}$} & \multicolumn{6}{|c|}{ UNIT } & \multirow{2}{*}{$\begin{array}{l}\text { JUMLAH } \\
\text { (Ton) }\end{array}$} \\
\hline & 1 & 2 & 3 & 4 & 5 & 6 & \\
\hline Nox & 47.08 & 49.76 & 58.92 & 0 & 0 & 0 & 155.77 \\
\hline $\mathrm{SO} 2$ & 0.98 & 1.03 & 1.22 & 0 & 0 & 0 & 3.24 \\
\hline $\mathrm{CO} 2$ & 3.09 & 3.26 & 3.87 & 0 & 0 & 0 & 10.23 \\
\hline \multicolumn{7}{|c|}{ TOTAL } & 169.25 \\
\hline
\end{tabular}

\section{B. Analisa}

Dari hasil simulasi penjadwalan kasus 1 yang didapat penjadwalan yang diberikan menunjukan penjadwalan yang sesuai dengan permintaan beban yang perlu dipenuhi, dengan kombinasi yang menghasilkan total biaya pembangkitan yang ekonomis. Dilihat dari hasil penjadwalan yang didapat tidak ada unit pembangkit yang melanggar syarat nyala dan padam minimum sesuai batasan yang diberikan pada table 3.1.

Penjadwalan yang diberikan pada kasus 2 memberikan kombinasi yang sesuai dengan kebutuhan beban yang diperlukan, dengan kondisi unit 6 yang selalu beroperasi, kondisi ini diperoleh karena ketersedian angin selama 24 jam selalu memadai unit 6 untuk beroperasi.

Dari hasil penjadwalan yang diberikan dapat dilihat tidak ada unit pembangkit yang melanggar persyaratan nyala dan padam minimum sesuai batas ada.

Dari penjadwalan yang sudah ditentukan maka tiap generator akan membangkitakan daya sesuai permintaan beban yang ada, dimana daya yang di hasilkan tiap unit pembangkit berbeda beda. Dari hasil perhitungan pembangkit pada kasus 1, menunjukan jumlah pembangkitan tiap unit pembangkit sesuai dengan permintaan beban yang ada dan tidak ada unit pembangkit yang menghasilkan daya yang melanggar batas maksimum dan minimum pembangkitan daya. Dapat dilihat dari hasil yang didapat, generator unit 4 tidak beroperasi sama sekali selama 24 jam, hal itu dikarenakan unit 4 tidak menjadi prioritas utama untuk beroperasi, sehingga jika permintaan beban masih bisa disuplai dari generator lain generator unit 4 tidak bekerja. Generator unit 4 tidak menjadi prioritas utama untuk berperasi disebabkan karena biaya operasioanal yang dimiliki unit 4 paling mahal dari unit yang lain, hal ini yang menyebabkan pengoperasian unit 4 sangat diminimalkan.
Hasil pembangkitan pada kasus 2 menunjukan total pembangkitan tiap generator mensuplai daya sesuai permintaan beban yang ada. Tiap generator juga mensuplai daya sesuai kapasitas yang dimiliki, sehingga tidak ada unit yang melanggar batas minimum dan maksimum pembangkitan. Berdasarkan penjadwalan yang dihasilkan pada kasus 2 dimana unit 6 selalu beroperasi karena ketersedian angin yang mencukupi. Unit 6 yang memiliki sumber pembangkit energy dari angin, sehingga unit 6 tidak memerlukan biaya pembangkitan, karena hal tersebut pengoperasian unit 6 sangat dimakasimalkan untuk memenuhi permintaan beban. Suplai daya yg diberikan unit 6 akan selalu maksimal sesuai dengan kecepatan angin yang tersedia.

Dari total pembangkitan tiap unit pembangkit dapat dilihat generator unit 6 menghasilkan daya paling banyak, pemaksimalan pembangkitan pada generator unit 6 karena dalam pembangkitan nya unit 6 tidak memerlukan biaya pembangkitan.

Hasil dari biaya pembangkitan merupakan penjumlahan dari biaya operasi ditambah dengan biaya penyalaan dan pemadaman generator. Biaya yang diberikan dalam satuan mata uang dollar. Hasil perhitungann biaya pada kasus 1 sangat beragam, sesuai dengan permintaan beban yang berubah ubah selama 24 jam. Biaya pembangkitan paling tertinggi terdapat pada jam ke 19 yaitu sebesar $\$ 43.10$, dimana beban pada jam tersebut adalah beban yang paling tinggi selama 24 jam yaitu sebesar 22.7 MW. Sedangkan biaya pembangkitan paling rendah terdapat pada jam ke 3 yaitu sebesar \$19.19, dimana beban pada jam tersebut adalah beban terendah selama 24 jam yaitu sebesar 11.35 MW. Total biaya pembangkitan yang diperlukan untuk mensuplai beban sebesar 416.18 MW selama 24 sebesar \$ 744.30.

Sedangkan pada kasus 2 biaya pembangkitan paling tinggi terdapat pada jam ke 19 juga yaitu sebesar \$ 31.1 beban yang perlu dipenuhi tidak berbeda yaitu sebesar 22.7 MW. Untuk biaya pembangkitan paling rendah terdapat pada jam ke 3 dengan permintaan beban sebesar 11.35 MW biaya yang diperlukan sebesar $\$ 9$ 9.46. Total biaya pembangkitan yang diperlukan unutk mensuplai beban yang sama dengan kasus 1 sebesar \$ 509.83

Dari dua kasus yang di uji dimana memiliki profil beban yang sama membutuhkan biaya pembangkitan yang berbeda, yaitu pada kasus 1 sebesar $\$ 744.3$ dan pada kasus 2 sebesar \$ 509.84. Perbedaan biaya pembangkitan yang diperlukan disebabkan oleh penggunaan turbin angin pada unit 6 di kasus 2. Penggunaan turbin angin ini sangat berpengaruh terhadapat biaya pembangkitan system, hal itu dapat dilihat dari selisih biaya yang diperlukan, dengan kata lain penggunaan turbin angin dapat menghemat biaya sebesar \$234.46.

Perhitungan emisi yang akan diberikan berupa perhitungan tiap jenis emisi yang dihasilkan oleh tiap unit pembangkit dalam satuan ton. Perhitungan emisi bergantung dengan besar daya unit pembangkit yang dihasilakn, yang akan dikalikan dengan factor emisi.

Pada kasus 1 total emisi yang dihasilkan selama 24 jam sebesar 236.62 ton, dengan jumlah emisi NOx paling besar yaitu 217.77 ton, di ikuti dengan $\mathrm{CO} 2$ sebesar 14.3 ton, dan SO2 sebesar 4.53 ton. Untuk unit pembangkit yang menghasilkan emisi paling banyak adalah generator unit 2 dengan total emisi yang dihasilkan sebesar 86 ton, dimana generator 2 menjadi generator penghasil daya terbesar 
dengan total pembangkitan selama 24 jam sebesar 151.3 MW. Untuk unit yang mengahsilkan emisi paling sedikit ada generator unit 6 dengan total emisi yang dihasilkan sebesar 1.63 ton, dimana generator unit 6 hanya menggenarasi daya sebesar $6 \mathrm{MW}$. Pada kasus 1 generator unit 4 tidak menghasilkan emisi karena unit 4 tidak beroperasi.

Pada kasus 2 total emisi yang dihasilkan sebesar 169.25 ton, dengan jumlah emisi NOx sebesar 155.77 ton, $\mathrm{CO} 2$ sebesar 10.23 ton, dan $\mathrm{SO} 2$ sebesar 3.24 ton. Unit pembangkit yang menghasilkan emisi paling bersar adalah unit 3 dengan total emisi yang dihasilkan sebesar 64 ton, dimana daya total yang digenerasikan pada unit 3 sebesar 112,62 MW. Dan unit pembangkit yang mengahasilkan emisi paling kecil adalah unit 1 dengan emisi total sebesar 51 ton, dengan daya total yang dihasilkan sebesar 90MW. Untuk unit 6 yang selalu beroperasi tiap jam nya dan menggenerasi daya total sebesar 113.9 MW tidak menghasilkan emisi, karena unit 6 menggunakan sumber energy terbarukan yang ramah lingkungan.

Jika dilihat dari kasus 1 dan kasus 2 emisi yang dihasilkan berbeda, yaitu sebesar 236.6 ton untuk kasus 1 dan 169.25 ton untuk kasus 2. Terdapat perbedaan emisi yang cukup besar antara kasus 1 dan kasus 2, dimana penggunaan turbin angin pada kasus 2 dapat mereduksi emisi sistem sebesar 67.4 ton

\section{V.KESIMPULAN}

Dari simulasi yang diperoleh didapatkan kesimpulan sebagai berikut:

1. Algoritma PSO dapat digunakan unutk mengoptimasi unit commitment agar mendapatkan biaya pembangkitan yang minimum tetapi tetap dapat memenuhi permintaan beban yang dibutuhkan.

2. Kondisi awal pembangkit berpengaruh terhadap waktu beroperasi nya unit pembangkit, dan biaya pembangkitan system karena ada nya biaya nyala dan mati unit pembangkit.

3. Pemaksimalan pengoperasian unit pembangkit dipengaruhi biaya operasi tiap unit pembangkit yang berbeda beda

4. Penggunaan turbin angin pada system pembangkitan berpengaruh besar terhadap biaya pembangkitan dan emisi yang dihasilkan

5. Dengan menggunakan turbin angin dapat menghemat biaya sebesar \$234.46, dan mereduksi emisi sebesar 67 ton

6. Hasil validasi tugas akhir ini dengan PowerGen memiliki selisih biaya pembangkitan sebesar $\$ 3.68$

\section{DAFTAR PUSTAKA}

[1] Allen J. Wood, Bruce F. Wollenberg, Power, Generation, Operation, and Control, John Willey \& Sons Inc, America, 1996.

[2] Mohamed Faisal A, Koivo Heikki., "System modeling and online optimal management of MicroGrid using Mesh Adaptive Direct Search", International Journal of Electrical Power \& Energy Systems., Vol. 32,no 5 2010, pp. 398-407.

[3] R.Reddy Gaddam,"Optimal Unit Commmitment Using Swarm Inteligence for Secure Operation of Solar Energy Integrated Smart Grid".Thesis of intenasional Institute Of Information Technologi,India,2013.

[4] Kennedy and Ebenhart, 1995 